THURSDAY, JUNE $7, \quad 1877$

\section{THE ANTIQUITY OF MAN}

TH $\mathrm{HE}$ Conference on the Antiquity of Man lately held by the Anthropological Institute, and reported in these columns, has led to a result by no means unsatisfactory, when all the conditions of the problem are duly weighed. The result is merely negative, but in arriving at it several misconceptions and errors of fact seem to us to have been swept away. In its discussion there were two parties represented, one eager to show that the antiquity of man has been proved by modern discovery to be far older than the date which had been arrived at by the Iabours of Falconer, Lyell, Prestivich, Evans, Boyd Dawkins, and others, while the other contended that the subject had not advanced in the least degree during the last few years, and that the so-called discoveries were either errors of observation, or resulting from premises which were altogether unsatisfactory. The field of the discussion lay in matters geological rather than archæological, and the caution which the president urged upon the conference was certainly not urged in vain.

The chief interest of the debate turned upon the question as to whether there was any evidence in this country of man in the caves or river deposits older than postglacial times. The readers of the works of Messrs. Croll and James Geikie will remember that they ascribe all the traces of palæolithic man in this country either to a preor intcr-glacial age, basing their conclusions principally upon the fact that in the river deposits and caves some of the associated animals, such as the hyæna, lion, and hippopotamus are now only to be found in hot climates ; and seeing that no traces of a warm climate are presented by any post-glacial deposit in Britain, they infer that those in question are of a much higher antiquity. They account for the association of southern and northern animals by the supposition that they occupied the country at different times, during glacial or interglacial æons of from five to twelve thousands years in length. To this it was objected that the intimate association of forms prove that both sets of animals inhabited the country at the same time, and were the result of the overlapping of different faunas during seasonal changes. The reindeer formed a large portion of the prey of the hyæna, and must therefore have been a contemporary. It was also pointed out by one of the speakers, that there is no evidence from the animals that there ever was anything like "the perpetual summer," advocated by Mr. Geikie at any time in the pleistocene age. The hippopotamus in Regent's Park takes his tub regularly in spite of the east winds so prevalent in the spring, which remind one of the glacial period; and the tiger crosses the frost-bound rivers of the Amoor to prey upon the reindeer. The lion, now found only in the south, lived in the days of Herodotus in the inclement mountains of Thrace. It seems, therefore, to us, that any argument based upon fossil animals as to a warm inter-glacial period, is worthless. And further, it is obviously unfair in treating of the fauna associated with man to adopt the forensic device of choosing some witnesses to the exclusion of others. It would be as easy to prove the climate in question to have been temperate from the associated remains of bison, stag, and horse, as it would be to prove it to have been arctic from the associated musk sheep, lemmings, and reindeer. It was probably a varying climate, with great extremes, similar to that in Central Siberia, in which the summer heat and winter cold are very severe.

The fossil mammalia of the pleiostocene tell us nothing as to the relation of man to the glacial period. The Arctic species invaded Europe probably from Asia, while the ice was finding its way southwards from the mountains of Scandinavia, and occupied the area north of the Alps and the Pyrenees, while the confluent glaciers covered the area north of the valley of the Thames. When the ice ultimately retreated they followed it, and thus were both pre- and post-glacial. Nor do the survivals from the pleiocene age tell us anything, such as the hippopotamus, the Rhinoceros leptorhinus, and the Elcphas antiquus, since they belong both to the earlier and later pleistocene strata, and are also associated with remains of reindeer, and other northern species. The presence of the reindeer in all the palæolithic caverns stamps the age of man as late pleistocene, according to Prof. Boyd Dawkins, but it does not afford any clue as to his pre- or post-glacial age. The glacial period is not a hard and fast line dividing one fauna from another. One palæolithic cave, however, in this country, that of Pont Newydd, in the valley of the Elwy, near St. Asaph, is of well-ascertained post-glacial age.

The argument urged in favour of palæolithic man being pre- or inter-glacial, based upon the distribution of the mammalia in southern and eastern England, and in France, while they are conspicuous by their absence in the glaciated areas of Scotland, Cumberland, and Wales, was met by the view that the barren areas were covered with ice, while other districts further to the south were occupied by the animals. The hypothesis that the uplands of Wales and Northern Britain were ever stocked by the same animals as the fertile river-bottoms of the south, seems to us little less than absurd. Yet this is necessary for the view that their remains have been removed from the barren areas by the subsequent grinding of the icesheet.

In the course of the discussion the reputed cases of the occurrence of palæolithic remains in the deposits older than the post-glacial were minutely criticised. Prof. Busk stated that the fibula of the Victoria Cave, formerly supposed to be human, was altogether too insignificant a fragment to base any conclusion upon as to man's antiquity. Two small cut-bones, however, of goat were brought forward by Mr. Tiddeman in support of the preor inter-glacial age of man in the Victoria Cave. On the other hand, it was urged that these were derived from the superficial stratum containing Roman coins and pottery, \&c., in which they were very abundant. From the nature of the cuts it seems to us that if it be established that they were discovered in the undisturbed stratum along with the hyænas, they would prove not only the presence of man, but of a user of a knife or chopper of bronze or iron. The absence of the goat, also (probably a domestic animal) from all undisturbed pleistocene deposits in this country, and in France, Belgium, and Germany, renders it very probable that the animal was introduced into those regions after the close of the pleistocene age. But even 
supposing that these difficulties be got over, the age of the deposit in which these fragments are stated to have been found is a matter of dispute in which the authorities are about equally balanced on either side.

The asserted inter-glacial age of the river gravels containing palæolithic implements proved equally unsatisfactory. The cases supposed to be decisive of the question in the neighbourhood of Brandon and Thetford, were considered by Prof. Hughes to throw no light upon it, $\sin \approx e$ the deposits above them, supposed to be boulder clay, are not boulder clay in situ. It was forcibly urged by several speakers, and especially by Prof. Prestwich, that the flint implemen:-bearing strata are proved by their position in the valleys to be later than the glaciation of the district, in every case where it has been glaciated, or in other words, that they are decidedly of post-glacial age.

The general question of the antiquity of man in Europe was not discussed, although we gathered that the evidence of the presence of man in the Italian pleiocenes was not considered satisfactory. The general impression left upon our minds is that in Britain there is no evidence of any palzolithic $m \in n$, either in caves or the river-deposits of an age older than post-glacial, and that the discoveries of the last fourteen years have merely given us interesting, details as to the paleeolithic savage, without telling us anything of his relation to the glacial period.

\section{TIEE VALUE OF NATURAL HISTORY MUSEUMS}

WELL-arranged museums are valuable to the state in many ways. The technological department ought to show in what new directions capital may and may not be invested ; the geological and mineralogical should point out in what kind of rock and in what parts of the earth's crust ores and minerals are to be sought, and should save the expenditure of money in useless trials. The museum of the Royal School of Mines in Jermyn Street performs these functions. But they are valuable in a still higher sense as encouraging a love of knowledge for its own sake apart from any selfish aims. The visitors to the British Museum, however frivolous they may be, leave it all the better for having been there. It is impossible that they should not carry away some sort of idea, which otherwise would not have occurred to them, even if it be merely the recognition that outside their daily lives there is a world of knowledge vast and indefinite, but real and tangible. In this respect museums are educators of the masses, offering them a means of culture which would otherwise be out of their reach. And lastly, as instruments of training in natural history they are, as I have already observed, as necessary to the student as collections of books to the student in arts.

Natural history pursuits are in themselves one of the forms of higher education, and one that is especially adapted for the culture of the lower, sometimes falsely termed the working classes - as if the higher classes worked neither with head nor hand. In proof of this I may quote the following example, which I am free to mention by the death of the man to whom it relates. Some years ago a mechanic, one of the evening class students at Owens College, took me to see a collection of fossils made by "a hand" in a cotton-mill at Oldham. To my astonishment I found that it consisted not merely of fossils an naturel, shells, and the like, but of those of coal plants, polished, and in many cases cut into slices so as to show their minute structure. This had been done by rubbing them down on the kitchen floor, cementing them to a piece of glass, and then grinding them until they became trans. parent. The care and labour implied in a process of this kind can only be estimated by those who have tried it. But it was necessary to have a microscope to see them, and I actually discovered that the instrument which was given me to use was made by the man himself, who could not afford to buy more than the lenses, which he mounted in tubes that were made to slide in each other after the manner of a telescope. He was also a good local botanist. His collection of fossils, along with another made by a friend of his under similar circumstances, furnished the materials on which Prof. W. C. Williamson has to a great extent founded his admirable memoirs on the coal-plants, now being published by the Royal Society. From time to time I saw a good deal of my friend, and a man more completely lifted out of the usual level of his class into what I may call the unselfish horizon I never met. This could be traced directly to the scientific pursuits to which he was led by seeing somebody one day pick up a piece of coal shale, and hearing him say that there was a fish scale in it. He disbelieved this, examined for himself, took to collecting, and ultimately became what he was, devoting his early mornings and his late everings not merely to collecting but to knowing. Fis knowledge embraced other things than naturai history. James Whittaker, of Oldham, may be taken as a type of the effect of natural history in elevating a man's character. He is the representative of a small, though very imporiant, body in the Northern Counties, a body which would be largely increased by the foundation of museums of the right sort. From fersonal coniact with men like him I have arrived at the conclusion that in this direction we have a means of spreading culture among the intelligent mechanics, artisans, and mill-hands, who go neither to church nor chapel, who do not read very much, and very often have no aims higher than those of the mere animal life. Had they access to museums on holidays and in the evenings, I am sure that the receipts of public houses would ultimately be lessened. At present they have few recreations and little chance of self-improve ment ; for the so-called mechanics' institutes, which were originally intended for them, have generally passed into the hands of the class immediately above them.

\section{W. BOYD DAWKINS}

\section{PHYSIOLOGICAL ESTHETICS}

Physiological Asthetics. By Grant Allan, B.A. Svo. (London: Henry S. King and Co., I877.)

X $\mathrm{E}$ have here a little work of some 300 pages, which deals with the philosophy of xsthetics almost exclusively on its physiological side. Of course, in thus restricting his subject, the author neglects all the more subtle and intricate parts of that philosophy; but every competent reader will agree with him that it is desirable, for the purpose of analysis, to separate as distincily as possible the physiological from the psychological elements 